\title{
Determination of the Antioxidant Potentials of Two Different Varieties of Banana Peels in Two Different Solvents
}

\author{
Jude Awele Okolie1, Olamide Emmanuel Henry², Emmanuel Ikedinachi Epelle ${ }^{3}$ \\ ${ }^{1}$ Department of Chemical Engineering, Michael Okpara University of Agriculture, Umudike, Nigeria \\ ${ }^{2}$ National Veterinary Research Institute, Vom, Plateau State, Nigeria \\ ${ }^{3}$ Department of Chemical Engineering, Federal University of Technology Minna, Minna, Nigeria \\ Email: judebebo32@gmail.com, epelsfutminna@yahoo.com, hentroy88@gmail.com
}

How to cite this paper: Okolie, J.A., Henry, O.E. and Epelle, E.I. (2016) Determination of the Antioxidant Potentials of Two Different Varieties of Banana Peels in Two Different Solvents. Food and Nutrition Sciences, 7, 1253-1261.

http://dx.doi.org/10.4236/fns.2016.713115

Received: May 14, 2016

Accepted: November 6, 2016

Published: November 9, 2016

Copyright $\odot 2016$ by authors and Scientific Research Publishing Inc. This work is licensed under the Creative Commons Attribution International License (CC BY 4.0).

http://creativecommons.org/licenses/by/4.0/ (c) (i) Open Access

\begin{abstract}
Fruit wastes which are perishable pose a big problem to pollution monitoring agencies; however these problems can be reduced by utilizing the high value compounds present in the food waste. Banana peels contain a reasonable number of antioxidant compounds such as gallocatechin and dopamine. This paper investigates the antioxidant potential of two different varieties of Banana peels (Dwarf cavandish and Musa omini). The peels were extracted with two different solvents (Methanol and Ethanol) using the soxhlet extractor. The results show that ethanolic extracts have higher phenolics and flavonoid contents (336.83 - 383.83 mgGAE/100g, 242.83 $252.82 \mathrm{mgRutin} / 100 \mathrm{~g}$ ) compared to the methanolic extracts of the same banana varieties (299.42 - $344 \mathrm{mgGAE} / 100 \mathrm{~g}, 240.77$ - $241.23 \mathrm{mgRutin} / 100 \mathrm{~g})$. However methanolic extracts exhibit higher DPPH Antioxidants Activity (30.82\% - 51.66\%) compared to ethanolic extracts $(25.44 \%-30.27 \%)$. This implies that antioxidative compounds other than phenolics and flavonoids were also involved in inhibiting the DPPH Radicals. It was also observed that at any concentration between $0.5-2.5 \mathrm{mg}$, ethanol extracts of both dwarf cavandish and musa omini had higher reducing power than the other two varieties.
\end{abstract}

\section{Keywords}

Antioxidants, Banana Peels, Phenolics, Extracts, Fruit Waste

\section{Introduction}

Fruit wastes are highly perishable and seasonal and they create problems to the 
processing industries and pollution monitoring agencies. These problems can be reduced by utilizing its high value compounds, including the dietary fibre fraction that has a great potential in the preparation of functional foods [1]. The peels of a variety of fruits have gained attention as a natural source of antioxidants and phytochemical content which are rich in compounds with free radical scavenging activity [2]. Banana peel, an underutilized source of phenolic compounds is considered as a good source of antioxidants for foods and functional foods against cancer and heart disease [3]. The peel of the fruit contains various antioxidant compounds such as gallocatechin and dopamine [1]. Recent trends focus on the isolation, characterization and utilization of natural antioxidants, especially growing interest in polyphenols as potential disease preventing agents. As these compounds are predominantly found in most of fruit tissues, it would be worthwhile investigating the nature of polyphenols that are present in banana peel, a potential source of antioxidant and antimicrobial activities. Antioxidants are important additive in gasoline; these antioxidants prevent the formation of gums that interfere with the operation of internal combustion engines [4].

An antioxidant is any substance which when present at low concentration compared to that of oxidizable substrates, significantly delays or inhibits oxidation of the substrate [5]. Oxidation is a chemical reaction that transfers electrons or hydrogen from a substance to an oxidizing agent; oxidation reaction can produce free radicals. In turn, these free radicals can start chain reactions. When the chain reaction occurs in a cell, it can cause damage or death to the cell [4]. Antioxidants terminate these chain reactions by removing free radical intermediates and inhibit other oxidation reactions; they do this by oxidizing themselves, so antioxidants are reducing agents such as thiols, ascorbic acids or polyphenols [6]. Primary sources of naturally occurring antioxidants are whole grains, fruits and vegetables.

Numerous methods have been proposed for measuring the antioxidant activities of food wastes; however the essential feature of any method includes the presence of a substrate, an oxidation initiator and an appropriate measurement of the end point. A simple and inexpensive method that can be used to analyze and measure the antioxidant capacity of food wastes involves the use of free radical, 2,2-Diphenyl-1-picrylhydrazyl (DPPH). The molecule of DPPH is characterized as a stable free radical by virtue of the delocalization of the spare electron over the molecule as a whole, so that the molecules do not dimerise, as would have been the case with most other free radicals [7]. The delocalization also gives rise to the deep violet colour, characterized by an absorption band in ethanol or methanol solution centered at about $520 \mathrm{~nm}$. When a solution of DPPH is mixed with that of a substance that can donate a hydrogen atom, it gives rise to a reduced form with the loss of this violet colour (although there would be expected to be a residual pale yellow colour from the picryl group still present) [8].

This paper elucidates the antioxidant activity of banana peel extracts, and it also analyzes the relationship between the phytochemical content and free radical scavenging activity of banana peels using the DPPH free scavenging activity and reducing power assay. 


\section{Materials and Methods}

\subsection{Feedstock Preparation}

Two varieties of banana dwarf cavanish and paranta (musa omini) were purchased from the "Uselu" market in Benin-City, Edo state, Nigeria. The peels were washed with distilled water and oven dried separately at $50^{\circ} \mathrm{C}$ and powdered using a lab grinder and stored in air tight jar at $4^{\circ} \mathrm{C}$ until use.

\subsection{Preparation of Ethanolic Extracts}

$32.24 \mathrm{~g}$ of powdered peel was packed in thimble flask and $550 \mathrm{ml}$ of ethanol $(70 \%)$ was added in 1 liter round bottom flask. Then the Soxhlet assembly was set up to complete 10 to 15 cycles of extraction. After that, the extract was filtered and filtrate was concentrated up to $50 \mathrm{ml}$ using water bath. From the concentrated $10 \mathrm{ml}$ of extract was taken in evaporating dish (Borosilicate glass) which is previously weighed. The total weigh of evaporating dish containing $10 \mathrm{ml}$ extract was recorded and the extract was evaporated till thick liquor was obtained. Thereafter, the calculated difference in weight was noted at every $10 \mathrm{~min}$ until the constant weigh was obtained. The residue at the constant weight is used as dry extractives, and stored until further use.

\subsection{Preparation of Methanolic Extracts}

$70.98 \mathrm{~g}$ of powdered peel was packed in thimble flask and $550 \mathrm{ml}$ of methanol (70\%) was added in 1 liter round bottom flask. Then the Soxhlet assembly was set up to complete 10 to 15 cycles of extraction. After that, the extract was filtered and the filtrate was concentrated up to $50 \mathrm{ml}$ using a waterbath. From the concentrated sample, $10 \mathrm{ml}$ of extract was taken in evaporating dish (Borosilicate glass) which is previously weighed. The total weigh of the evaporating dish containing $10 \mathrm{ml}$ extract was recorded and the extract was evaporated till thick liquor was obtained. Subsequently, the difference in weight was noted at every $10 \mathrm{~min}$ until the constant weigh was obtained. The residue at the constant weight is used as dry extractives, and stored until further use.

\subsection{Preparation of Gallic Acid Standard Curve}

Gallic acid stock solution was prepared by dissolving $0.2 \mathrm{~g}$ of dry gallic acid in $10 \mathrm{ml}$ of methanol and diluted to a volume of $100 \mathrm{ml}$ with distilled water. For the sodium carbonate solution, $20 \mathrm{~g}$ of anhydrous sodium carbonate was dissolved in $80 \mathrm{ml}$ of distilled water and brought to boil. In order to prepare the calibration curve, $0,1,2,3,4$, and 5 $\mathrm{ml}$ of the above stock solution in $100 \mathrm{ml}$ volumetric flasks were diluted to volume with distilled water. These solutions will have concentrations of $0,20,40,60,80$ and 100 $\mathrm{mg} / \mathrm{l}$ gallic acid. For each calibration solution, pipette $0.5 \mathrm{ml}$, to each solution, $2 \mathrm{ml}$ of distilled water and $0.5 \mathrm{ml}$ of Follin-Ciocalteu reagents were added and mixed well, for 8 minutes before adding $0.5 \mathrm{ml}$ of sodium carbonate solution for thirty minutes at $40^{\circ} \mathrm{C}$. Absorbance of each solution is measured using a spectrometer at $765 \mathrm{~nm}$ and a standard curve was obtained by plotting absorbance against the gallic acid concentration. 
From the curve obtained, the total phenolic contents of banana peel extracts were determined by comparing its absorbance with standard values.

\subsection{Preparation of Quercetin Standard Curve}

Quercetin stock solution was prepared by dissolving $0.2 \mathrm{~g}$ of dry quercetin in $10 \mathrm{ml}$ of methanol and diluted to a volume of $100 \mathrm{ml}$ with distilled water. To prepare the calibration curve, $0,1,2,3,4$, and $5 \mathrm{ml}$ of the above stock solution in $100 \mathrm{ml}$ volumetric flasks were diluted to volume with distilled water. These solutions will have concentrations of $0,20,40,60,80$ and $100 \mathrm{mg} / \mathrm{l}$ quercetin. For each calibration, pipette different amount of sample in $3.0 \mathrm{ml}$ of distilled water to which $0.3 \mathrm{ml}$ of $5 \%$ sodium nitrite was added and properly mixed. After 5 minutes at room temperature, $0.6 \mathrm{ml}$ of $10 \%$ Aluminium chloride was added; $2 \mathrm{ml}$ of $1 \mathrm{M}$ sodium hydroxide was added after 6 minutes and absorbance was read at $510 \mathrm{~nm}$. A standard curve was obtained by plotting absorbance against the quercetin concentration. From the curve obtained, the total flavonoid contents of banana peel extracts were determined by comparing its absorbance with standard.

\subsection{Analysis of the Total Phenolics Contents (TPC)}

Samples were analyzed for total polyphenol content according to the Folin-Ciocalteu method [9]. To $0.5 \mathrm{ml}$ aliquot of the extract solution, $0.2 \mathrm{ml}$ of Folin-Ciocalteau reagent, and a saturated solution of $\mathrm{Na}_{2} \mathrm{CO}_{3}(0.5 \mathrm{ml})$ was added. This was increased to 10 $\mathrm{ml}$ with distilled water and incubated at $27^{\circ} \mathrm{C}$ for $30 \mathrm{~min}$. Optical density was measured at $765 \mathrm{~nm}$ using a spectrophotometer. The concentration was calculated using gallic acid as a standard and the results were expressed as gallic acid equivalents/100g of sample.

\subsection{Analysis of the Total Flavonoid Contents (TFC)}

TFC of the extracts were determined according to the colorimetric assay following the procedure of Sultana et al. (2008) [10] with some modifications. 1 milliliter of aqueous extract containing $0.01 \mathrm{~g} / \mathrm{ml}$ of dry matter was placed in a $10 \mathrm{ml}$ volumetric flask, and then $5 \mathrm{ml}$ of distilled water was added. At zero time, $0.3 \mathrm{ml}$ of $(5 \% \mathrm{w} / \mathrm{v}) \mathrm{NaNO}_{2}$ was added. After $5 \mathrm{~min}, 0.6 \mathrm{ml}$ of ( $10 \% \mathrm{w} / \mathrm{v}) \mathrm{AlCl}_{3}$ was added. After another $5 \mathrm{~min}, 2 \mathrm{ml}$ of 1 $\mathrm{M}$ solution of $\mathrm{NaOH}$ was added. After that, the volume was made up to $10 \mathrm{ml}$ with distilled water. The mixture was shaken vigorously and the absorbance of the pink color of mixture was read at $510 \mathrm{~nm}$ using a UV-visible spectrophotometer. A calibration curve was prepared using a standard solution of quercetin within the range 10 - $100 \mathrm{ppm}$ (R2 $=0.9962$ ) and the results were expressed as mg quercetin equivalents $/ 100 \mathrm{~g}$ of dry matter. All samples were analyzed in triplicates and results averaged.

\subsection{Reducing Power}

In this assay, $\mathrm{Fe}^{3+} /$ ferricyanide complex is reduced to the ferrous form by antioxidants. $\mathrm{The}^{2+} \mathrm{e}^{2+}$ formed is monitored by measuring the formation of Perl's Prussian blue at 700 
$\mathrm{nm}$ [11]. Different amounts of sample in $1.0 \mathrm{ml}$ of distilled water were mixed with phosphate buffer $(2.5 \mathrm{ml}, 0.2 \mathrm{M}, \mathrm{pH} 6.6)$ and potassium ferricyanide $\left[\mathrm{K}_{3} \mathrm{Fe}(\mathrm{CN})_{6}\right](2.5$ $\mathrm{ml}, 1 \%)$. The mixture was incubated at $50^{\circ} \mathrm{C}$ for $20 \mathrm{~min}$. A portion $(2.5 \mathrm{ml})$ of trichloroacetic acid (10\%) was added to the mixture, which was then centrifuged at $3000 \mathrm{rpm}$ for $10 \mathrm{~min}$. The upper layer of the solution $(2.5 \mathrm{ml})$ and $\mathrm{FeCl}_{3}(0.5 \mathrm{ml}, 0.1 \%)$ were mixed and the absorbance was measured at $700 \mathrm{~nm}$. Increased absorbance of the reaction mixture indicated increased reducing power.

\subsection{Free Radical Scavenging Activity Using DPPH}

The antioxidant capacity of the banana peel extracts was studied through the evaluation of the free radical-scavenging effect on the 1,1-diphenyl-2-picrylhydrazyl (DPPH) radical. The determination was assessed by using procedure reported by Sultana et al. (2008) [10] with slight modifications. $5.0 \mathrm{ml}$ of a freshly prepared solution of 1,1-diphenyl-2-picrylhydrazyl (DPPH) methanolic solution at concentration $0.025 \mathrm{~g} / \mathrm{l}$ was added to $1.0 \mathrm{ml}$ of extract containing $25 \mu \mathrm{g} / \mathrm{ml}$ of dry matter in methanol. The mixture was shaken and kept in the dark and left to stand at room temperature for $30 \mathrm{~min}$. The absorbance of the resulting solution was measured at $515 \mathrm{~nm}$, against a blank of methanol without DPPH, using a UV-visible spectrophotometer. Results were expressed as percentage of inhibition of the DPPH radical which was calculated according to the following equation: Radical scavenging activity $(\%)=($ Control OD - Sample OD/ Control OD) $\times 100)$.

\section{Results and Discussion}

\subsection{Physical Characteristics of the Peels}

The physical characteristics of the peel are given in Table 1. Fresh musa omini banana peels were yellow in colour while dwarf cavandish were green in colour; however, significant darkening was observed on drying both peels. The extract yield of powdered peel obtained was more in musa omini $(8.97 \%$ - 15.41\%). Similarly ethanol extracts produces more yield than methanol extracts in dwarf cavandish peels while methanol extracts produces more yield in musa omini peels. Variations in yields of extracts might be attributed to the availability of different extractable components, defined by the chemical composition, nature of the soil and agro-climatic conditions [12].

\subsection{Analysis of the Total Phenolic Contents (TPC)}

Table 2 shows the TPC of two different varieties of banana peel extracts using Gallic

Table 1. Physical characteristics of the peel.

\begin{tabular}{cccccc}
\hline \multirow{2}{*}{ Sample } & \multicolumn{2}{c}{ Colour } & Weight of & \multicolumn{2}{c}{ Yield \% } \\
\cline { 2 - 3 } \cline { 5 - 6 } & Fresh & Dry & sample (g) & Methanol extracts & Ethanol extracts \\
\hline Musa omini (paranta) & Yellow & Brown & 70.98 & 15.41 & 8.97 \\
Dwarf cavandish & Green & Brown & 70.98 & 3.10 & 3.32 \\
\hline
\end{tabular}


Table 2. Total phenolic contents of two different varieties of banana peels in different extracts.

\begin{tabular}{ccc}
\hline \multirow{2}{*}{ Solvents } & \multicolumn{2}{c}{ Banana varieties } \\
\cline { 2 - 3 } & Total phenolic content (mg gallic acid/100g sample) \\
\hline \multirow{2}{*}{ Dethanol } & $344.29 \pm 30.86$ & Musa omini (paranta) \\
Ethanol & $383.33 \pm 29.46$ & $299.42 \pm 21.21$ \\
\end{tabular}

Each value is expressed as the mean \pm standard error $(n=3)$.

Table 3. Total flavonoid contents of two different varieties of banana peels in different extracts.

\begin{tabular}{ccc}
\hline \multirow{2}{*}{ Solvents } & \multicolumn{2}{c}{ Banana varieties } \\
\cline { 2 - 3 } & Total flavonoid content $($ mg quercetin/100g sample) \\
\hline & $241.23 \pm 30.86$ & Musa omini (paranta) \\
\hline Methanol & $252.82 \pm 29.46$ & $240.77 \pm 21.21$ \\
Ethanol & & $242.83 \pm 17.40$
\end{tabular}

Each value is expressed as the mean \pm standard error $(n=3)$.

Acid standard curve with $\mathrm{R}^{2}=0.993$. Phenolics contents for the banana peel samples analyzed in this study ranges from 299.42 to $383.33 \mathrm{GAE} / 100 \mathrm{~g}$ samples. Phenolics contents in ethanol extracts varied from 336.83 to $383.33 \mathrm{mg}$ GAE/100g samples. Compared to ethanol extracts, methanol extracts showed less phenolics contents which ranged from 299.42 - $344.29 \mathrm{mgGAE} / 100 \mathrm{~g}$ samples.

\subsection{Analysis of the Total Flavonoid Contents (TFC)}

The TFC of the peels are given in Table 3. Flavonoid contents of banana peel samples analyzed in this sample ranges from $240.77 \mathrm{mg}$ Rutin/100g sample to $252.82 \mathrm{mg} \mathrm{Ru}-$ tin/100g samples. TFC in ethanol extracts varied from 242.83 to $252.82 \mathrm{mg}$ Rutin/100g samples, compared to ethanol extracts, methanol extracts showed less flavonoid contents which ranged from 241.23 to $240.77 \mathrm{mg}$ Rutin/100g samples.

\subsection{Reducing Power Assay}

Figure 1 shows the relationship between the reducing power of two different varieties of banana peel extracts. It was observed that at any concentration between $0.5-2.5 \mathrm{mg}$, ethanol extracts of both dwarf cavandish and musa omini had higher reducing power than the other two varieties. Similarly, from Table 1, it can be observed that the ethanolic extracts of both banana peel varieties had high phenolic contents than their corresponding methanolic extracts, hence there is a close relationship between the amount of total phenolic content and the reducing power. Also the reducing power of the extracts increases slightly with an increase in concentration as shown in Figure 1. Hence, it is necessary to determine the reducing power of phenolics contents to elucidate the relationship between their antioxidant effects and their reducing power [13]. 


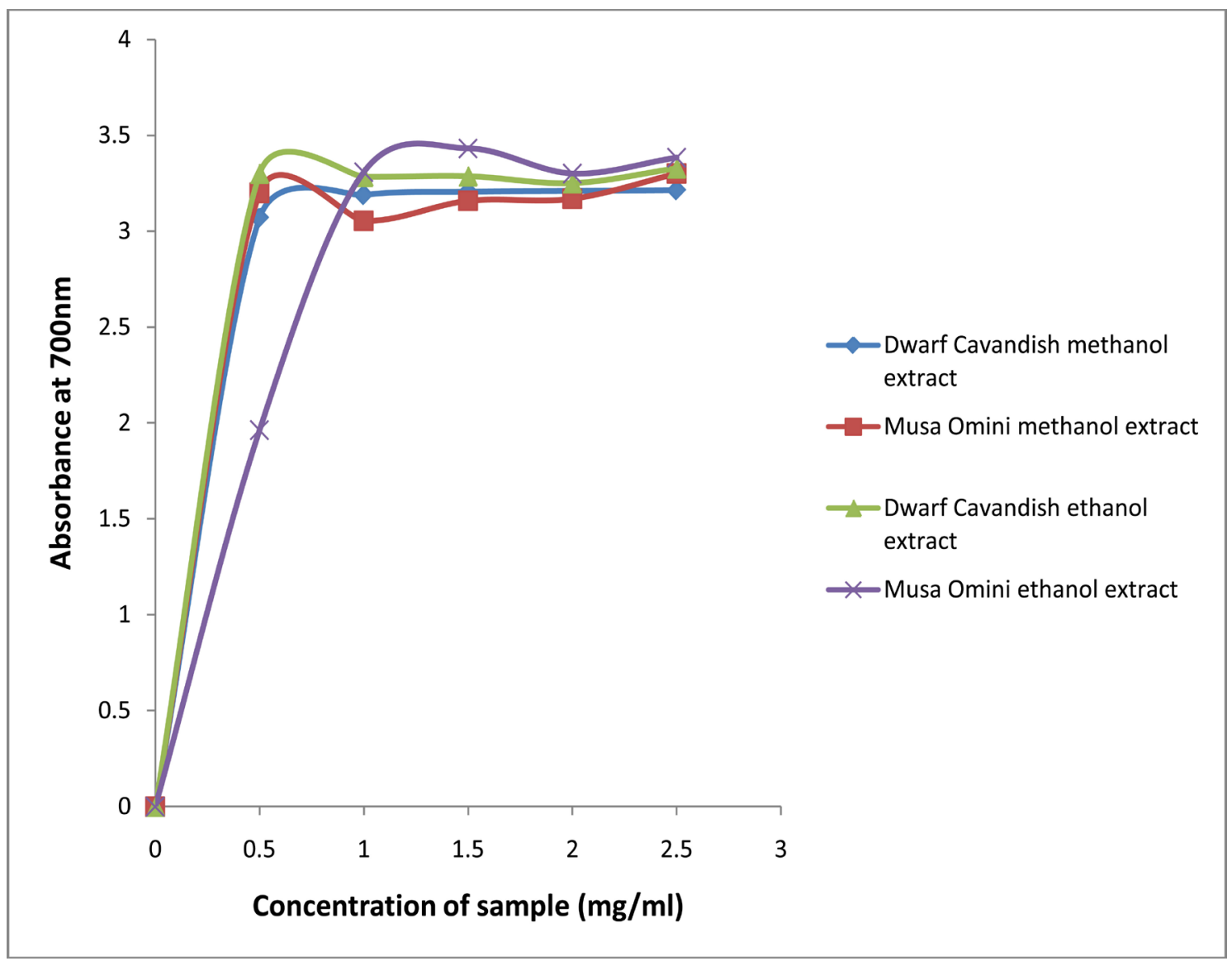

Figure 1. Reducing power of two varieties of banana peels in different extracts.

\subsection{Free Radical Scavenging Activity}

DPPH Free Radical Scavenging Activity is plotted as a function of a sample concentration in Figure 2. The inhibition of DPPH Radical of the banana peel ranged from $2.2 \%$ to $51.66 \%$. Methanol extracts of musa omini showed higher activity (51.66\%) compared to ethanol extracts (30.27\%). A similar trend was observed in the case of dwarf cavandish peel where methanol extracts had an activity of (30.82\%) compared to dwarf cavandish extracts (25.44\%). This is consistent with those reported by Alothmant et al., (2009) [14], Choo and Azis (2010) [15]. Among the two varieties, musa omini peel exhibited higher antioxidant activity at lesser concentration. As reported in literature, the strong antioxidative properties of banana extracts could be due to different antioxidant components present [1]. DPPH inhibition should follow a similar order of the total phenolic and flavonoid contents, i.e. as the concentration of the phenolics compounds or the degree of hydroxylation of the phenolics compounds increases, the DPPH Radical Scavenging Activity also increases [14]. This is however not the case in this study, even though musa omini and dwarf cavandish were ranked quite low in terms of TFC and TPC; their antioxidant activities were higher compared to that of the ethanolic extracts of both varieties of banana peels. This implies that antioxidative compounds other than phenolics and flavonoids were also involved in inhibiting the DPPH Radicals. 




Figure 2. Free radical scavenging activity in different banana peel extracts.

Compounds such as ascorbic acids, $\alpha$-carotene and different xanthophylls have been detected in banana and may have contributed to the antioxidant activity of the extracts [16].

\section{Conclusion}

This study shows that the total phenolic and flavonoid contents were higher in ethanolic extracts compared to methanolic extracts. The ethanolic extracts of Dwarf cavandish and Musa omini banana peels also have higher reducing power compared to methanol extracts of the same varieties; however methanolic extracts exhibit higher antioxidants activity compared to ethanolic extracts. This implies that antioxidative compounds other than phenolics and flavonoids were also involved in inhibiting the DPPH radicals. It can thus be concluded that solvents play a vital role in the extraction of plant constituents. 


\section{References}

[1] Kanazawa, K. and Sakakibara, H. (2000) High Content of Dopamine, a Strong Antioxidant in Cavendish Banana. Journal of Agricultural Food Chemistry, 48, 844-848. http://dx.doi.org/10.1021/jf9909860

[2] Arawande, J.O. and Komolafe, E.A. (2010) Antioxidative Potentials of Banana and Plantain Peel Extracts on Crude. Ethnobotanical Leaflets, 14, 559-569.

[3] Someya, S., Yoshiki, Y. and Okubo, K. (2002) Antioxidant Compounds from Bananas (Musa cavendish). Food Chemistry, 79, 351-354. http://dx.doi.org/10.1016/S0308-8146(02)00186-3

[4] Dabelstein, W., Reglitzky, A., Schutze, A. and Reders, K. (2007) Automotive Fuels. In: Ullmann's Encyclopedia of Industrial Chemistry, Wiley-VCH Verlag GmbH \& Co. KGaA, Weinheim. http://dx.doi.org/10.1002/14356007.a16 719.pub2

[5] Halliwell, B. and Gutteridge, J.M.C. (1989) Free Radicals in Biology and Medicine. 2nd Edition, Oxford Science Publications, Clarendon.

[6] Helmut, S. (1997) Oxidative Stress. Experimental Physiology, 82, 291-295. http://dx.doi.org/10.1113/expphysiol.1997.sp004024

[7] Songklanakarin, J. (2004) The Use of the Stable Free Radical Diphenylpicrylhydrazyl (DPPH) for Estimating Antioxidant Activity. Songklanakarin Journal of Science and Technology, 26, 211-219.

[8] Blois, M.S. (1958) Antioxidant Determinations by the Use of a Stable Free Radical. Nature, 181, 1199-1200. http://dx.doi.org/10.1038/1811199a0

[9] Mathaus, B. (2002) Antioxidant Activity of Extracts Obtained from Residues of Different Oil Seeds. Journal of Agricultural and Food Chemistry, 50, 3444-3452. http://dx.doi.org/10.1021/jf011440s

[10] Sultana, B., Anwar, F. and Iqbal, S. (2008) Effect of Different Cooking Methods on the Antioxidant Activity of Some Vegetables from Pakistan. International Journal of Food Science \& Technology, 43, 560-567. http://dx.doi.org/10.1111/j.1365-2621.2006.01504.x

[11] Oyaizu, M. (1986) Studies on Product of Browning Reaction Prepared from Glucose Amine. Japanese Journal of Nutrition, 44, 307-315.

http://dx.doi.org/10.5264/eiyogakuzashi.44.307

[12] Hsu, B. Coupar, I.M. and Ng, K. (2006) Antioxidant Activity of Hot Water Extract from the Fruit of the Doum Palm Hyphaenethebaica. Food Chemistry, 98, 317-328. http://dx.doi.org/10.1016/j.foodchem.2005.05.077

[13] Shan, X., Liu, Z., Dong, Z., Wang, Y., Chen, Y., et al. (2005) Mobilization of the Active MITE Transposons mPing and Pong in Rice by Introgression from Wild Rice (Zizania latifolia Griseb.). Molecular Biology and Evolution, 22, 976-990. http://dx.doi.org/10.1093/molbev/msi082

[14] Alothman, M., Bhat, R. and Karim, A.A. (2009) Antioxidant Capacity and Phenolic Content of Selected Tropical Fruits from Malaysia, Extracted with Different Solvents. Food Chemistry, 115, 785-788. http://dx.doi.org/10.1016/j.foodchem.2008.12.005

[15] Choo, C.L. and Azis, N.A.A. (2010) Effects of Banana Flour and $\beta$-Glucan on the Nutritional and Sensory Evaluation of Noodles. Food Chemistry, 119, 34-40.

http://dx.doi.org/10.1016/j.foodchem.2009.05.004

[16] Subagio, A., Morita, N. and Sawada, S. (1996) Carotenoids and Their Fatty-Acid Esters in Banana Peel. Journal of Nutritional Sscience and Vitaminology, 42, 553-566. http://dx.doi.org/10.3177/jnsv.42.553 
Submit or recommend next manuscript to SCIRP and we will provide best service for you:

Accepting pre-submission inquiries through Email, Facebook, LinkedIn, Twitter, etc.

A wide selection of journals (inclusive of 9 subjects, more than 200 journals)

Providing 24-hour high-quality service

User-friendly online submission system

Fair and swift peer-review system

Efficient typesetting and proofreading procedure

Display of the result of downloads and visits, as well as the number of cited articles

Maximum dissemination of your research work

Submit your manuscript at: http://papersubmission.scirp.org/

Or contact fns@scirp.org 